\title{
Growth of Brahman cross heifers to 2 years of age in the dry tropics
}

\author{
Geoffry Fordyce ${ }^{\mathrm{A}, \mathrm{C}}$ and Kerri Chandra ${ }^{\mathrm{B}}$ \\ A University of Queensland, Queensland Alliance for Agriculture and Food Innovation, St Lucia, \\ Qld 4072, Australia. \\ ${ }^{B}$ Department of Agriculture and Fisheries, Dutton Park, Qld 4102, Australia. \\ ${ }^{\mathrm{C} C o r r e s p o n d i n g ~ a u t h o r . ~ E m a i l: ~ g . f o r d y c e @ u q . e d u . a u ~}$
}

\begin{abstract}
Growth of 1368 Brahman cross heifers from 6 year cohorts was monitored over the 2 years post-weaning in Australia's northern forest, a low-animal-growth dry tropical environment. Heifers weighing 47-266 kg at weaning were managed in groups weighing $<100 \mathrm{~kg}, 100-149 \mathrm{~kg}, 150-199 \mathrm{~kg}$, and $>199 \mathrm{~kg}$ during the post-weaning dry season. Weaner heifers were allocated to receive $300 \mathrm{~g} /$ day of a protein meal during the dry season or to basic nutritional management to sustain health. Heifers in three cohorts were allocated to first mating at 1 or 2 years of age, in four cohorts to vaccination against androstenedione, and in a small proportion of two cohorts to ovariectomy post-weaning. Growth was highly variable between seasons and years; average cohort liveweight by the start of 2-year-old mating was 256-319 kg. Heifer groups not receiving protein supplementation gained -16 to $21 \mathrm{~kg}$ (2 kg average) during 6-month dry seasons, and 49-131 kg (101 kg average) during wet seasons to reach an average of two-thirds of mature liveweight $(445 \mathrm{~kg})$ and $95 \%$ of mature hip height $(1350 \mathrm{~mm})$ by the start of mating at 2 years. Average body condition score (1-5) fluctuated by $1-2$ units between seasons. Hip height gain continued, irrespective of season, commencing at $\sim 0.60 \mathrm{~mm} /$ day at 6 months of age, and decelerating by $\sim 0.00075 \mathrm{~mm} /$ day through to 2.5 years of age. Standard errors of predicted means across analyses were $\sim 0.015$ for average daily weight gains, $0.4 \mathrm{~mm}$ for average monthly height gain and 0.06 score units for average seasonal body condition score change. Post-weaning dry-season supplementation increased gains in liveweight, height and body condition score by an average of $0.1 \mathrm{~kg} / \mathrm{day}, 0.1 \mathrm{~mm} /$ day and $0.5 \mathrm{units}$, respectively, during the supplementation period. Periods of poor nutrition or high nutritional demand secondary to reproduction suppressed daily gains in liveweight and hip height, at which times body condition score was also reduced. Subsequent to this, partial to full compensation occurred for all measures. Ovariectomy had negative effects on growth. Androstenedione vaccination had no effect on growth. The main conclusion is that heifer growth in Australia's dry tropical northern forest region is highly variable between seasons and years, thus limiting significant proportions of some cohorts from reaching target weights for mating at 2 years of age, even after compensatory growth.
\end{abstract}

Additional keywords: body condition, cattle, compensatory growth, height, tropical, weight.

Received 5 October 2016, accepted 21 August 2017, published online 7 December 2017

\section{Background}

The overall expression of growth is liveweight gain, which is a function of growth of the musculoskeletal system, along with growth of all other body systems. There are limited reports on the growth of beef heifers in the dry tropics of northern Queensland (Holroyd et al. 1990; Fordyce et al. 1993b; Barwick et al. 2009). There are even fewer reports of skeletal measures and growth for tropically adapted cattle in northern Australia (Barwick et al. 2009; Wolcott et al. 2014) than there are of liveweight gain, and no specific reported studies on non-genetic interventions to manage heifer growth.

In survey data reported for north of the Tropic of Capricorn in Australia, Bortolussi et al. (2005) reported median annual steer growth at $90-136 \mathrm{~kg}$ for $71 \%$ of 392 beef businesses. Much of this region is classed as northern forest by McGowan et al. (2014) who reported median potential steer growth of $100 \mathrm{~kg} / \mathrm{year}$ for 16 properties with an interquartile range of $90-130 \mathrm{~kg} / \mathrm{year}$.
The primary reasons for low growth are low-fertility soils that are commonly phosphorus-deficient (McCosker and Winks 1994), and low, highly variable rainfall.

McGowan et al. (2014) reported that $63 \%$ of 32 study herds in the northern forest were continuously mated, a function of insufficient infrastructure to control bulls in very large paddocks. This results in calves being born year-round, and because it is also a low-growth environment weaning occurs 2-3 times per year. Therefore, calves at weaning have a large variation in age and weight. Weaning of calves as light as $100 \mathrm{~kg}$, and at times lighter, is not uncommon. McGowan et al. (2014) reported a median weaner weight of $163 \mathrm{~kg}$ with an interquartile range for average weaner weight of $152-174 \mathrm{~kg}$ in the northern forest region. If calves are weaned at $<150 \mathrm{~kg}$ on to nutrient-deficient pastures, they require protein and energy supplementation, and if $<100 \mathrm{~kg}$ require a high-protein ration, to sustain health and growth, thus increasing chances of survival until wet season rains 
(Fordyce and Holroyd 2003). Though recommended, such nutritional management is not always provided, and this may be partially because the specific benefits to growth, subsequent fertility, and business profitability of low-level nutritional support for weaner heifers of all ages has not previously been reported.

There are many anecdotal reports of poor heifer growth in tropical Australia associated with low pregnancy rates. Growth influences time of puberty in heifers, thus pregnancy rates when mated as maidens at either 1, 2 or 3 years of age - all three occur in tropical Queensland. Johnston et al. (2009) reported that liveweight at first evidence of puberty was $330-334 \pm 45 \mathrm{~kg}$ for north Australian cattle. If heifer growth is $8 \%$ lower in females than males (Fordyce et al. 1993a), in average years not more than $70 \%$ of heifers are likely to be able to conceive by 2.5 years of age based on the data above. This is consistent with the report by McGowan et al. (2014) who found a median of $67 \%$ of heifers pregnant with an interquartile range of $40-81 \%$ for this region.

Puberty is the culmination of maturation of the hormonal systems that support ovarian follicular development through to ovulation and subsequent pregnancy if it occurs. During maturation, there is sustained negative feedback from oestradiol-17 $\beta$ on the hypothalamus until late in the process when this feedback switches to positive which supports the final stages of maturation (Kinder et al. 1995). Oestrogens are also known to affect growth (Lui and Baron 2011). It was hypothesised that vaccination against a closely related hormone, androstenedione, may reduce the impact of oestradiol-17 $\beta$ during pre-pubertal development and advance puberty and growth (D'Occhio et al. 1988).

Poor bull control in the region results in unwanted pregnancies in heifers. Ovariectomy (spaying) is a common practice to prevent pregnancies in those selected for slaughter rather than breeding. Apart from recovery from surgery, this practice removes ovarian hormone supply as stated above. The longerterm effect of these changes on heifer growth in northern Australia had not been reported before this research.

This study aimed to document the growth of Brahman cross heifers post-weaning to 2.5 years of age in the northern forest of Queensland, and to determine the impact of nutritional and hormonal interventions on liveweight, body condition and skeletal growth.

\section{Method}

All experiments were approved by the Swan's Lagoon Animal Experimentation and Ethics Committee under the guidelines of 'The Australian Code for the care and Use of Animals for Scientific Purposes' (National Health and Medical Research
Council: https://www.nhmrc.gov.au/guidelines-publications/ea28, accessed 27 October 2017).

The research was conducted over eight consecutive years from 1987 to 1995 with six heifer cohorts weaned in 1987 and 1989 to 1993.

\section{Site}

The studies were conducted at Swan's Lagoon Research Station $\left(20.0^{\circ} \mathrm{S}, 147.3^{\circ} \mathrm{E}\right)$ in the sub-coastal dry tropics. This is within the area recently described by McGowan et al. (2014) as northern forest, which encompasses low-animal-growth tropical forested country across northern Australia. General climatic conditions from data collected on the station are summarised in Table 1. The station has predominately low-fertility duplex soils that have low available phosphorus levels averaging $6 \mathrm{mg} / \mathrm{kg}$ (Smith et al. 2001). The vegetation is an open eucalypt savannah woodland with a pasture predominated by three main grass species: Heteropogon contortus, Bothriochloa petusa, and Chrysopogon fallax. The vegetation supports cattle growth predominantly in the hot moist period, the wet season, commencing with the start of the storm season. Growth typically reduces to maintenance in the cool dry period (early dry season) and progresses to weight loss in the hot dry period (late dry season).

\section{Animals and animal management}

The cattle used in this study were mostly red tropically adapted crossbreds that were $\sim 50 \%$ Bos indicus and $50 \%$ Bos taurus. The primary source breeds were Brahman and Beef Shorthorn, with small proportions of Angus, Hereford, Sahiwal and other unidentified breeds. Average mature cow liveweight at $445 \mathrm{~kg}$ and hip height at $1350 \mathrm{~mm}$ when aged 5 years or more, in moderate body condition, and non-pregnant (Smith et al. 2001) were similar to averages of $460 \mathrm{~kg}$ and $1370 \mathrm{~mm}$, respectively, reported for 50\% Bos indicus cows across north Queensland (McGowan et al. 2014).

A closed herd was maintained from 1985 with replacement breeding animals selected for high growth, good temperament, high calf output, tropical adaptation (to heat, poor nutrition, ectoparasites, and endemic infectious diseases transmitted by tropical ectoparasites), sound udders and teats and attractive conformation. The herd was continuously mated and calves were weaned twice yearly (in early May and late August). Weaners therefore ranged in age from 2 to 11 months, and were separated at weaning into groups based on their liveweight $(<100 \mathrm{~kg}, 100-150 \mathrm{~kg},>150 \mathrm{~kg})$.

Six heifer year-of-weaning cohorts were enrolled in this study, with most being selected from the first annual weaning in May. The heifers were randomly selected from within the

Table 1. Swan's Lagoon climate from on-site records, 1966-2007

\begin{tabular}{lcccc}
\hline & \multicolumn{2}{c}{ Average temperature $\left({ }^{\circ} \mathrm{C}\right)$} & \multicolumn{2}{c}{ Median } \\
Maximum & Minimum & rainfall (mm) & $\begin{array}{c}\text { Average relative } \\
\text { humidity (\%) at 9am }\end{array}$ \\
\hline Dec.-Apr. (Wet season-Hot moist) & 32 & 21 & 498 & 72 \\
May-Aug. (Early-dry season-Cool dry) & 27 & 12 & 55 & 70 \\
Sept. -Nov. (Late dry season-Hot dry) & 32 & 17 & 45 & 60 \\
\hline
\end{tabular}


entire cohort available. Table 2 details the distribution of heifer weaner weights in each cohort. In 1989 when extremely wet conditions prevented treatment allocation, heifers weaned at different times within the same liveweight category were differentiated by an extra digit in their group description.

All heifers were vaccinated against botulism. At all times, heifers had ready access to plentiful pasture and clean water in troughs. If required for survival, heifers were supplemented in addition to their treatment. On average, this was needed for a few weeks every 3-5 years (Fig. 1). Heifers were grazed at approximately one adult equivalent (equivalent to a $454 \mathrm{~kg}$ steer) per 4 ha.
Treatments and management

At weaning, heifers were allocated to a range of treatments by stratified randomisation on their weaning weight. The different treatments included nutritional supplementation, hormonal treatments (androstenedione vaccine and ovariectomy at weaning or 7.5 months of age), and mating age. Table 3 details the allocation of animals in each weaner weight category to the different treatments. Except for the 1989 and 1992 cohorts, each weaning weight $\times$ treatment group was replicated $2-3$ times (Table 3 ). At the end of the dry season post-weaning, when average heifer age was approximately 1 year, each allocated cell of heifers was equally and randomly distributed

Table 2. Number of heifers recruited to the study in each weaner size group in each cohort

\begin{tabular}{lccccccc}
\hline Weaner size $^{\mathrm{A}}$ & $\begin{array}{c}\text { Weaner size } \\
\text { abbreviation }\end{array}$ & 1987 & 1989 & 1990 & 1991 & 1992 & 1993 \\
\hline Very small $(<100 \mathrm{~kg})$ & WV & - & 47 & - & - & - & - \\
Small: $100-149 \mathrm{~kg}$ & WS & 37 & 63 & 70 & 78 & 76 & 76 \\
Average: $150-200 \mathrm{~kg}$ & WA & 201 & 119 & 169 & & 75 & 72 \\
Average-small: $150-170 \mathrm{~kg}$ & W1 & - & - & - & 75 & 72 & - \\
Average-big: $170-199 \mathrm{~kg}$ & W2 & - & - & - & 77 & 72 & - \\
Big: $>200 \mathrm{~kg}$ & WB & - & - & - & - & - & 68
\end{tabular}

${ }^{\mathrm{A}}$ Variations - 1987: WA >149 kg; 1991: WS <149 kg, W2 >172 kg; 1992: WS <142 kg, W2 >167 kg; 1993: WS <144 kg and WB $>186 \mathrm{~kg}$

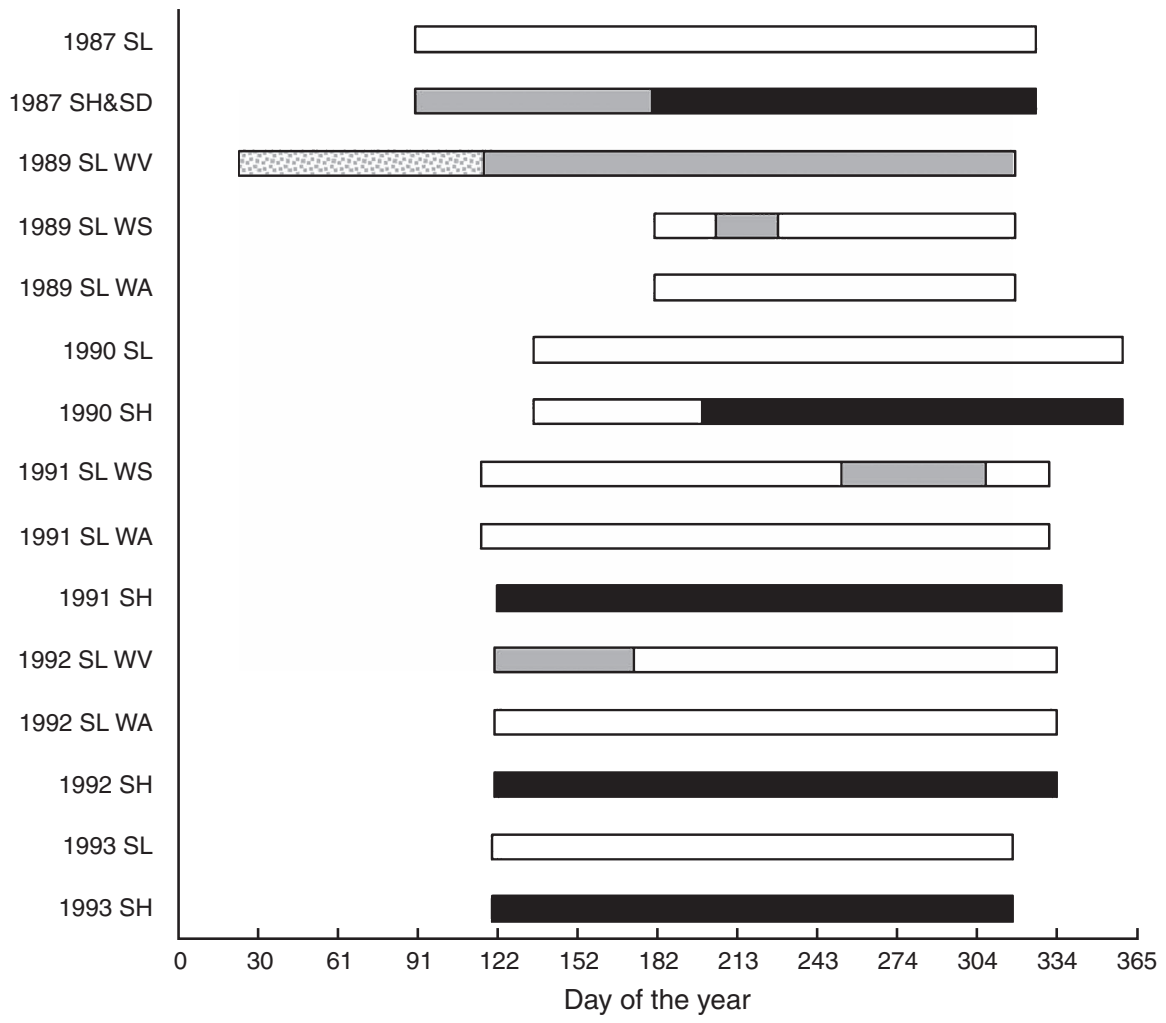

Fig. 1. Supplementation of heifers between weaning and the end of the dry season each year: blank = no supplement; grey $=a d$ lib. molasses with $10 \%$ cotton seed meal and $5 \%$ urea; stippled $=1 \mathrm{~kg} /$ day.heifer of $16 \%$ protein pellets; black $=2.1 \mathrm{~kg} /$ week.heifer of cottonseed meal; digits = year cohort; $\mathrm{SL}=$ basic supplementation to sustain health; $\mathrm{SH}=$ protein meal supplementation; $\mathrm{WV}=$ weaned at $<100 \mathrm{~kg}$; WS $=$ Weaned 100-149 kg; WA = Weaned 150-200 kg. 
Table 3. Number of heifers allocated to treatments at weaning

\begin{tabular}{|c|c|c|c|c|c|c|c|}
\hline \multirow[t]{2}{*}{ Allocation and treatment abbreviation } & & \multicolumn{6}{|c|}{ Cohort } \\
\hline & & 1987 & 1989 & 1990 & 1991 & 1992 & 1993 \\
\hline \multirow{2}{*}{\multicolumn{2}{|c|}{$\begin{array}{l}\text { Total heifers } \\
\text { Replicates of treatment } \times \text { weaner size }\end{array}$}} & 238 & 229 & 239 & 230 & 220 & 216 \\
\hline & & 2 & 0 & 2 & 3 & 1 & 2 \\
\hline \multicolumn{8}{|c|}{ Heifers per treatment } \\
\hline \multicolumn{8}{|l|}{ Dry season supplement } \\
\hline Basic supplementation only & SL & 88 & & 119 & 60 & 55 & 108 \\
\hline \multicolumn{8}{|l|}{ Androstenedione vaccine } \\
\hline No vaccine & V0 & - & - & 139 & - & - & 142 \\
\hline Injections $0,1,3$ and 5 months post-weaning & VA & - & - & 100 & $60^{\mathrm{D}}$ & $55^{\mathrm{D}}$ & $74^{\mathrm{B}}$ \\
\hline Maiden mating age (mate) & & & - & - & - & - & - \\
\hline Mate to calve at 2 years of age & M1 & - & - & - & $50^{\mathrm{D}}$ & $55^{\mathrm{D}}$ & 108 \\
\hline Mate to calve at 3 years of age & M2 & - & - & - & - & - & 108 \\
\hline
\end{tabular}

${ }^{A}$ Post-weaning supplement amounts were $2450 \mathrm{~g} /$ week for 2 months and then $3150 \mathrm{~g} /$ week for 3 months.

${ }^{\mathrm{B}} \mathrm{WB}$ heifers were not allocated to Androstenedione vaccination treatments.

${ }^{\mathrm{C}}$ Three heifers in each weaner size $\times$ dry season supplement combination (no WB) were allocated to OS.

${ }^{\mathrm{D}}$ Only SH heifers.

to graze two paddocks till the start of mating at $\sim 26$ months of age. Heifers were then allocated within their original weaner liveweight and treatment replicate and yearling paddock to one of three paddocks where they joined mixed-age herds of $~ 300$ cows mated at 3 bulls per 100 females.

\section{Nutritional treatments}

The impact of providing $300 \mathrm{~g} /$ day of a protein meal, a low-level energy and protein supplement, in the post-weaning dry season was investigated over 5 years. The impact of repeating this supplementation in the second dry season was trialled in the 1987 cohort. Based on visual appraisal of animal health and available pasture, basic supplementation was only provided where it was needed to sustain health. It was not offered when it was obviated by availability of pasture that provided abovemaintenance diets, i.e., during the dry seasons of 1990, 1991 and 1993. If required, weaners $<100 \mathrm{~kg}$ were fed $a d \mathrm{lib}$. calf pellets (16\% crude protein) and heavier weaner groups were offered ad lib. fortified molasses ( $3 \%$ urea and $10 \%$ cottonseed meal), distributed twice weekly as 4-and 3-day rations. Fig. 1 details the type and duration of nutritional supplements offered in the post-weaning dry season to each weaner size and treatment group in each cohort.

\section{Hormonal treatments}

Preparation of a vaccine against androstenedione is described by D'Occhio et al. (1988). Heifers allocated to vaccination (1990-1993; Table 3) were injected subcutaneously 0, 1, 3 and 5 months post-weaning.

Ovariectomy (1990, 1993; Table 3) was conducted at weaning or at 7.5 months of age by flank laparotomy, which was standard regional practice at that time. Time of ovariectomy was selected for secondary studies of ovarian development.
After local analgesia was applied to standing heifers and the surgical site disinfected, the skin was incised anterior to the left tubal coxa in an anterio-ventral direction. The peritoneum was incised after blunt dissection through abdominal muscles. Each ovary was located manually, cut from its attachments using shielded scalpels guided immediately adjacent to the ovary, and removed from the abdomen, after which absorbable sutures were inserted to close the skin.

\section{Mating age treatments}

Most heifers in the study were first mated at 2 years of age, except those allocated to yearling mating in the 1991-1993 cohorts (Table 3). Heifers mated as yearlings remained segregated as a group from 12 months of age until weaning of their calves the following year when they were again reunited with heifers firstmated at 2 years of age. Each yearling-mated cohort was mated to two fertile 2-year-old bulls of the same breed for 12 weeks from mid-January when they were $\sim 15$ months of age. Mating was continuous from 2 years of age.

\section{Measurements}

Heifers were mustered at least every 2 months. The standard protocol was to muster and weigh heifers before they would normally come to water in the morning. At each weighing, body condition score was assessed on a 9-point scale (CS9; Holroyd 1978). To achieve conformity with more-recent standards, the scores were transformed to a 5-point scale (CS5; Gaden 2005) using the equation $\mathrm{CS} 5=3+(\mathrm{CS} 9-6) \times 2 / 3$. Height was measured at the peak of the sacrum (hip height) at seasonal interfaces. Average daily gains and changes in liveweight, body condition score and height were calculated for the seasonal periods described in Table 1. 


\section{Statistical analyses}

The data for each cohort were analysed separately due to different experimental designs in each year. Analyses were performed using REML (residual maximum likelihood; Payne et al. 2008) methods for all growth variables on each day and season for which data were recorded (Table 4). Repeatedmeasures analyses were performed on weight, body condition score and height in the post-weaning dry season and from approximately 1 year of age until the time of mating at 2 years of age. In repeated-measures analyses where a sufficient number of well-spaced records were taken over the periods, analyses were performed both with and without the inclusion of splines. A step-down method of removing non-significant interactions was used for all models.

\section{Results}

Growth of heifers was highly variable and strongly associated with rainfall patterns. Rainfall measured during the study period is shown in Fig. 2. On average, heifers lost 1-2 body condition score units and gained little liveweight during dry seasons $(12 \mathrm{~kg}$ from 6 to 12 months; $-1 \mathrm{~kg}$ from 17-24 months), and recovered body condition with an average gain of $103 \mathrm{~kg}$ during wet seasons (Tables 4, 5; Fig. 3). They reached an average of twothirds of mature liveweight at $\sim 26$ months of age. In contrast, hip height gain was steady and gradually decreasing through to $\sim 29$ months of age, even during periods of liveweight and body condition loss (Tables 4-6; Fig. 3); average hip height gains in respective 6-month periods after weaning were $97 \mathrm{~mm}, 75 \mathrm{~mm}$, $42 \mathrm{~mm}$ and $21 \mathrm{~mm}$. At $\sim 26$ months of age, heifers averaged $95 \%$ of mature hip height, having gained in the 21 months from weaning, an average of $74 \%$ of the $30 \mathrm{~cm}$ average gain expected in the 4 years after weaning (the average difference in hip heights between weaning and maturity). Standard errors of the predicted means across analyses were typically at or close to 0.015 for average daily weight gains, $0.4 \mathrm{~mm}$ for average monthly height gain and 0.06 score units for average seasonal body condition score change.

Table 4. Factors included in analytical models for each cohort

\begin{tabular}{|c|c|c|c|c|c|c|c|}
\hline \multirow{2}{*}{\multicolumn{2}{|c|}{ Factors and how they were included in analytical models }} & \multicolumn{6}{|c|}{ Cohort } \\
\hline & & 1987 & 1989 & 1990 & 1991 & 1992 & 1993 \\
\hline \multicolumn{8}{|c|}{ Single time and seasonal change analyses } \\
\hline \multirow[t]{9}{*}{ Fixed } & Weaner size & $\mathrm{x}$ & $x^{A}$ & $\mathrm{x}$ & $\mathrm{x}$ & $\mathrm{x}$ & $\mathrm{x}$ \\
\hline & Weaning weight covariate & $\mathrm{x}$ & $\mathrm{x}$ & $\mathrm{x}$ & $\mathrm{x}$ & $\mathrm{x}$ & $\mathrm{x}$ \\
\hline & Breed & $\mathrm{x}$ & - & - & - & - & - \\
\hline & Dry season supplement & $\mathrm{x}$ & $\mathrm{x}$ & $\mathrm{x}$ & $\mathrm{x}$ & $\mathrm{x}$ & $\mathrm{x}$ \\
\hline & Androstenedione vaccination & - & - & - & $\mathrm{x}$ & $\mathrm{x}$ & $\mathrm{x}$ \\
\hline & Ovariectomy & - & - & $\mathrm{x}$ & - & - & $\mathrm{x}$ \\
\hline & Maiden mating age & - & - & & $\mathrm{x}$ & $\mathrm{x}$ & $\mathrm{x}$ \\
\hline & Paddock: $1-2$ years of age (within Mating age) & & & $\mathrm{x}$ & $\mathrm{x}$ & $\mathrm{x}$ & $\mathrm{x}$ \\
\hline & Replicate & $\mathrm{x}$ & - & $\mathrm{x}$ & $\mathrm{x}$ & - & $\mathrm{x}$ \\
\hline Random & Post-weaning dry season paddock & $\mathrm{x}$ & - & $\mathrm{x}$ & $\mathrm{x}$ & - & $\mathrm{x}$ \\
\hline \multicolumn{8}{|c|}{ Repeated-measures analyses - additional factors } \\
\hline Fixed & Day and its significant interactions & $\mathrm{x}$ & $\mathrm{x}$ & $\mathrm{x}$ & $\mathrm{x}$ & $\mathrm{x}$ & $\mathrm{x}$ \\
\hline \multirow[t]{2}{*}{ Random } & Heifer & $\mathrm{x}$ & $\mathrm{x}$ & $\mathrm{x}$ & $\mathrm{x}$ & $\mathrm{x}$ & $\mathrm{x}$ \\
\hline & Heifer.Day interaction & $\mathrm{x}$ & $\mathrm{x}$ & $\mathrm{x}$ & $\mathrm{x}$ & $\mathrm{x}$ & $\mathrm{x}$ \\
\hline
\end{tabular}

${ }^{\mathrm{A}}$ Combination of weaner size and weaning age.

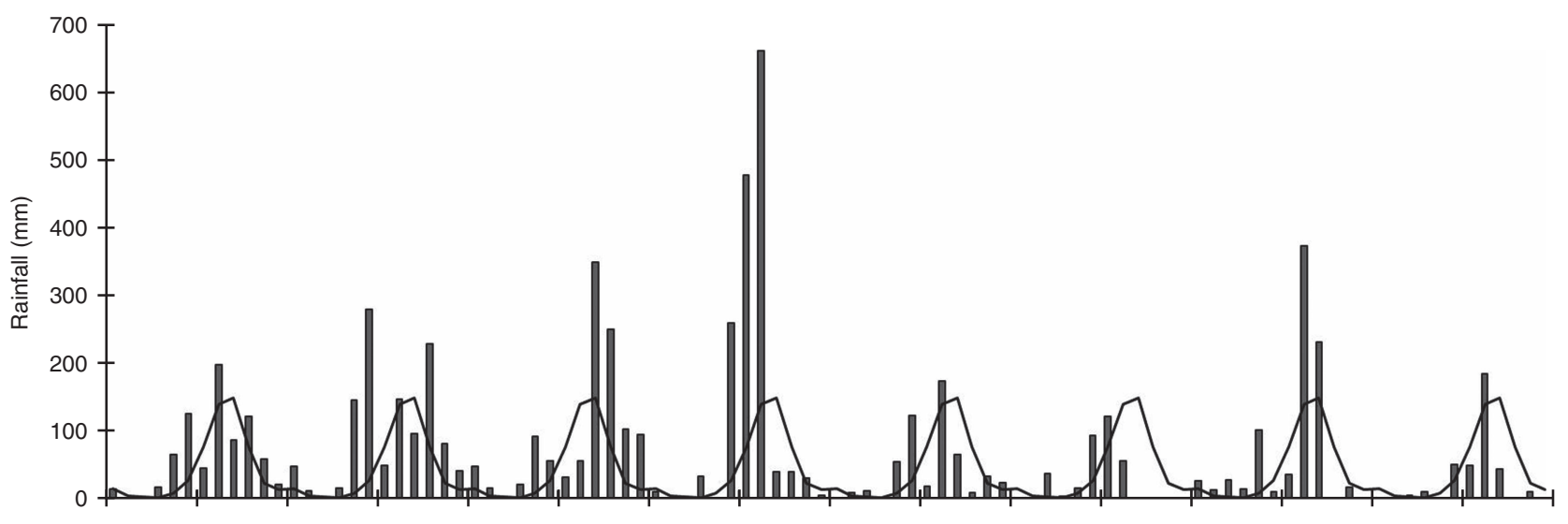

June-87 Dec.-87 June-88 Dec.-88 June-89 Dec.-89 June-90 Dec.-90 June-91 Dec.-91 June-92 Dec.-92 June-93 Dec.-93 June-94 Dec.-94

Fig. 2. Monthly rainfall during the study period: bars = recorded rainfall; line = median rainfall. 
Table 5. Weaner size and dry season supplement effects on heifer weights and heights up to 2 years of age (see Tables 2 and 3 for treatment abbreviations)

Means with different letters within cohort $\times$ parameter time/period differ significantly $(P<0.05)$

\begin{tabular}{|c|c|c|c|c|c|c|c|c|c|c|c|c|}
\hline \multirow{2}{*}{\multicolumn{2}{|c|}{ Time/Season: }} & \multicolumn{6}{|c|}{ Weights (kg) } & \multicolumn{5}{|c|}{ Hip heights (mm) } \\
\hline & & \multirow{2}{*}{$\begin{array}{c}\text { Weaning } \\
5\end{array}$} & \multirow{2}{*}{$\begin{array}{c}\text { Wet } \\
\text { start } \\
12\end{array}$} & \multirow{2}{*}{$\begin{array}{l}\text { Mate } \\
1 \text { year } \\
14\end{array}$} & \multirow{2}{*}{$\begin{array}{c}\text { April-May } \\
17\end{array}$} & \multirow{2}{*}{$\begin{array}{c}\text { Wet } \\
\text { start } \\
24\end{array}$} & \multirow{2}{*}{$\begin{array}{l}\text { Mate } \\
2 \text { year } \\
26\end{array}$} & \multirow{2}{*}{$\begin{array}{c}\text { Weaning } \\
5\end{array}$} & \multirow{2}{*}{$\begin{array}{c}\text { Wet } \\
\text { start } \\
12\end{array}$} & \multirow{2}{*}{$\begin{array}{c}\text { April-May } \\
17\end{array}$} & \multirow{2}{*}{$\begin{array}{c}\text { Wet } \\
\text { start } \\
24\end{array}$} & \multirow{2}{*}{$\begin{array}{l}\text { Mate } \\
2 \text { year } \\
26\end{array}$} \\
\hline $\begin{array}{l}\text { Averag } \\
\text { age }(\end{array}$ & $\begin{array}{l}\text { eifer } \\
:\end{array}$ & & & & & & & & & & & \\
\hline \multicolumn{13}{|c|}{ Post-weaning dry season supplement } \\
\hline \multirow{3}{*}{1987} & SL & 165 & $146 \mathrm{a}$ & $235 \mathrm{a}$ & $281 \mathrm{a}$ & $279 \mathrm{a}$ & $319 a$ & $1067 \mathrm{a}$ & $1116 \mathrm{a}$ & 1223 & 1264 & - \\
\hline & SH & 163 & $173 b$ & $249 b$ & $297 b$ & $290 \mathrm{~b}$ & $330 \mathrm{~b}$ & $1059 b$ & $1136 b$ & 1238 & 1272 & - \\
\hline & SD & - & - & - & $301 b$ & $302 \mathrm{c}$ & $340 \mathrm{c}$ & - & - & - & 1280 & - \\
\hline \multirow[t]{2}{*}{1989} & SL & $132 \mathrm{a}$ & $159 \mathrm{a}$ & $215 \mathrm{a}$ & $275 \mathrm{a}$ & $255 \mathrm{a}$ & $258 \mathrm{a}$ & - & - & - & - & - \\
\hline & SH & $117 \mathrm{~b}$ & $152 b$ & $204 b$ & $260 b$ & $244 \mathrm{~b}$ & $248 b$ & - & - & - & - & - \\
\hline \multirow[t]{2}{*}{1990} & SL & 153 & $161 \mathrm{a}$ & $176 a$ & $210 \mathrm{a}$ & $196 a$ & $256 \mathrm{a}$ & - & $1117 \mathrm{a}$ & $1177 \mathrm{a}$ & 1221 & - \\
\hline & $\mathrm{SH}$ & 153 & $186 \mathrm{~b}$ & $197 b$ & $232 b$ & $213 b$ & $273 b$ & - & $1134 b$ & $1191 b$ & 1227 & - \\
\hline \multirow[t]{2}{*}{1991} & SL & 160 & $153 \mathrm{a}$ & $205 \mathrm{a}$ & $267 \mathrm{a}$ & $266 a$ & $326 a$ & 1065 & 1129 & 1219 & 1278 & - \\
\hline & SH & 159 & $166 \mathrm{~b}$ & $219 b$ & $278 b$ & $274 \mathrm{~b}$ & $334 b$ & 1062 & 1139 & 1225 & 1276 & - \\
\hline \multirow[t]{2}{*}{1992} & SL & 154 & $165 \mathrm{a}$ & $198 \mathrm{a}$ & $249 \mathrm{a}$ & $252 a$ & $286 \mathrm{a}$ & 1048 & $1152 \mathrm{a}$ & $1210 \mathrm{a}$ & 1261 & - \\
\hline & SH & 154 & $184 \mathrm{~b}$ & $223 b$ & $278 \mathrm{~b}$ & $268 \mathrm{~b}$ & $302 b$ & 1044 & $1171 b$ & $1224 b$ & 1265 & - \\
\hline \multirow[t]{2}{*}{1993} & SL & 169 & $163 a$ & $193 a$ & $279 \mathrm{a}$ & 301 & 269 & 1077 & $1154 \mathrm{a}$ & 1238 & 1285 & 1278 \\
\hline & $\mathrm{SH}$ & 169 & $182 \mathrm{~b}$ & $208 b$ & $292 b$ & 307 & 272 & 1074 & $1172 b$ & 1245 & 1283 & 1279 \\
\hline \multicolumn{13}{|c|}{ Weaner size group } \\
\hline \multirow[t]{2}{*}{1987} & WS & $149 \mathrm{a}$ & $146 \mathrm{a}$ & $226 a$ & $271 \mathrm{a}$ & $272 \mathrm{a}$ & $314 \mathrm{a}$ & 1044 & 1105 & 1215 & 1259 & - \\
\hline & WA & $178 b$ & $174 b$ & $257 \mathrm{~b}$ & $315 b$ & $302 b$ & $342 b$ & 1082 & 1146 & 1246 & 1279 & - \\
\hline \multirow[t]{7}{*}{$1989^{\mathrm{A}}$} & WV1 & $86 a$ & $161 \mathrm{c}$ & $217 \mathrm{c}$ & $279 d$ & $260 \mathrm{bc}$ & $264 b$ & - & - & - & - & - \\
\hline & WV2 & $87 \mathrm{ab}$ & $144 b$ & $199 b$ & $258 b$ & $238 \mathrm{a}$ & $242 \mathrm{a}$ & - & - & - & - & - \\
\hline & WV3 & $100 \mathrm{~b}$ & $132 \mathrm{a}$ & $181 \mathrm{a}$ & $241 \mathrm{a}$ & $227 \mathrm{a}$ & $232 \mathrm{a}$ & - & - & - & - & - \\
\hline & WS1 & $129 \mathrm{c}$ & $157 \mathrm{c}$ & $211 \mathrm{c}$ & $271 \mathrm{c}$ & $252 b$ & $257 b$ & - & - & - & - & - \\
\hline & WS2 & $137 d$ & $146 b$ & $197 b$ & $253 \mathrm{ab}$ & $238 \mathrm{a}$ & $241 \mathrm{a}$ & - & - & - & - & - \\
\hline & WA1 & $158 \mathrm{e}$ & $175 d$ & $233 \mathrm{e}$ & $293 \mathrm{e}$ & $271 d$ & $275 c$ & - & - & - & - & - \\
\hline & WA2 & $174 \mathrm{f}$ & $174 d$ & $229 \mathrm{~d}$ & $278 \mathrm{~d}$ & $261 \mathrm{c}$ & $261 b$ & - & & & & \\
\hline 1990 & WS & $132 \mathrm{a}$ & $154 a$ & $169 a$ & $204 a$ & $192 a$ & $249 a$ & - & $1092 \mathrm{a}$ & $1158 \mathrm{a}$ & $1204 a$ & - \\
\hline & WA & $173 b$ & $193 b$ & $204 b$ & $237 b$ & $241 \mathrm{~b}$ & $279 b$ & - & $1158 b$ & $1211 b$ & $1251 b$ & - \\
\hline 1991 & WS & $134 \mathrm{a}$ & $151 \mathrm{a}$ & $203 a$ & $261 \mathrm{a}$ & $259 \mathrm{a}$ & $320 \mathrm{a}$ & $1017 \mathrm{a}$ & $1110 \mathrm{a}$ & $1205 \mathrm{a}$ & $1260 \mathrm{a}$ & - \\
\hline & W1 & $161 b$ & $161 b$ & $212 b$ & $274 b$ & $272 b$ & $331 b$ & $1068 b$ & $1135 b$ & $1221 b$ & $1275 b$ & - \\
\hline & W2 & $184 \mathrm{c}$ & $180 \mathrm{c}$ & $237 \mathrm{c}$ & $295 \mathrm{c}$ & $290 \mathrm{c}$ & $348 c$ & $1105 \mathrm{c}$ & $1168 \mathrm{c}$ & $1247 \mathrm{c}$ & $1294 \mathrm{c}$ & - \\
\hline 1992 & WS & $128 \mathrm{a}$ & $157 \mathrm{a}$ & $189 \mathrm{a}$ & $241 \mathrm{a}$ & $243 a$ & $275 \mathrm{a}$ & $997 \mathrm{a}$ & 1131a & $1190 \mathrm{a}$ & $1240 \mathrm{a}$ & - \\
\hline & W1 & $154 \mathrm{~b}$ & $183 b$ & $220 \mathrm{~b}$ & $270 \mathrm{~b}$ & $264 \mathrm{~b}$ & $299 b$ & $1051 b$ & $1170 \mathrm{~b}$ & $1228 b$ & $1268 b$ & - \\
\hline & W2 & $181 \mathrm{c}$ & $184 b$ & $223 b$ & $279 \mathrm{c}$ & $273 c$ & $308 \mathrm{c}$ & $1088 \mathrm{c}$ & $1197 \mathrm{c}$ & $12345 \mathrm{c}$ & $1285 \mathrm{c}$ & - \\
\hline 1993 & WS & $128 \mathrm{a}$ & $147 \mathrm{a}$ & $175 a$ & $255 \mathrm{a}$ & $274 a$ & $252 \mathrm{a}$ & $1015 \mathrm{a}$ & $1116 a$ & $1211 \mathrm{a}$ & $1261 \mathrm{a}$ & $1257 \mathrm{a}$ \\
\hline & WA & $163 b$ & $167 \mathrm{~b}$ & $196 \mathrm{~b}$ & $280 \mathrm{~b}$ & $298 b$ & $269 \mathrm{~b}$ & $1066 b$ & $1154 \mathrm{~b}$ & $1232 b$ & $1275 \mathrm{a}$ & $1268 \mathrm{~b}$ \\
\hline & WB & $217 \mathrm{c}$ & $204 c$ & $231 \mathrm{a}$ & $322 \mathrm{c}$ & $340 \mathrm{c}$ & $290 \mathrm{c}$ & $1145 \mathrm{c}$ & $1220 \mathrm{c}$ & $1280 \mathrm{c}$ & $1317 b$ & $1311 \mathrm{c}$ \\
\hline
\end{tabular}

${ }^{\mathrm{A}}$ Heifers weaned at different times within the liveweight category at weaning were differentiated by an extra digit in their group description.

Change in body condition was almost invariably negatively correlated between seasons, i.e., heifers within treatment groups losing more condition during dry seasons, gained more in preceding or ensuing wet seasons; $r=0.0$ to -0.9 for 82 of 83 calculations within year $\times$ weaner size $\times$ weaning supplementation groups. No consistent relationship existed between liveweight gains in the post-weaning dry season and the subsequent wet season. However, within treatment groups, $81 \%$ of correlations between heifer liveweight change in their second dry season (at 18-24 months of age) and liveweight gain in either the preceding or subsequent wet seasons were negative. Similarly, there was also a low trend for height gain during wet seasons to be negatively associated with gain during adjacent dry seasons; $72 \%$ of correlations were negative.
Growth of unsupplemented heifers was highly variable between years. Average cohort liveweight at 26 months of age varied from 256 to $319 \mathrm{~kg}$ (Table 5). The range in average hip heights at the same age was $5 \mathrm{~cm}$. The 1991 cohort had the lowest gains of all cohorts in liveweight, body condition score and hip height during the post-weaning dry season, a function of seasonal conditions (Figs 2, 3). From the end of the post-weaning dry season, the 1987 and 1990 cohorts, respectively, had the highest and lowest liveweight and height gains, and generally had the highest and lowest body condition scores. Wet season growth was lowest in the 1990 cohort at $50 \mathrm{~kg}$ and $5 \mathrm{~cm}$ (wet season finished early), and highest in the 1987 cohort at $134 \mathrm{~kg}$ and $11 \mathrm{~cm}$ (long wet season). Similarly, there was a large range in dry season growth, being lowest in the 1993 cohort at 
(a)
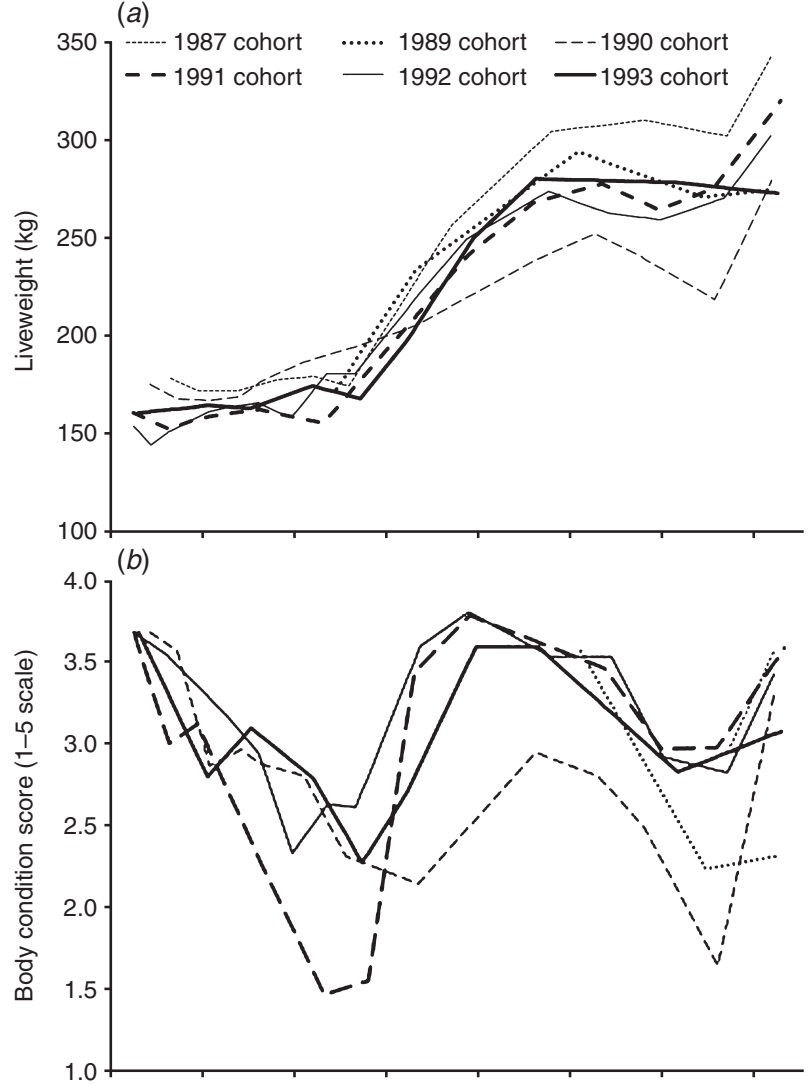

(c)

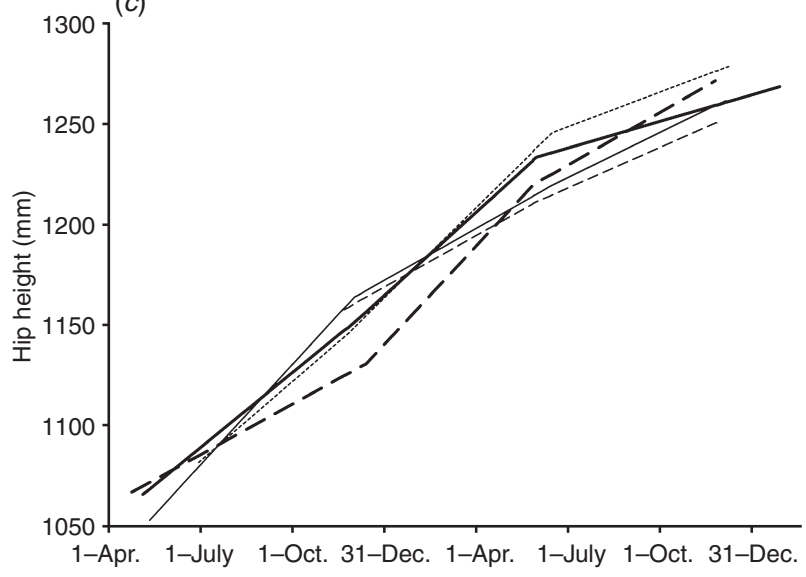

Fig. 3. Average (a) liveweights, $(b)$ body condition scores and (c) hip heights over the study period for each heifer cohort (raw data).

17-24 months of age $(-21 \mathrm{~kg}$ and $+5 \mathrm{~cm})$ and highest in the 1990 cohort at the same age $(+14 \mathrm{~kg}$ and $+4 \mathrm{~cm})$.

Low-level post-weaning dry season supplementation ( $300 \mathrm{~g} /$ day of cottonseed meal) increased gains in liveweight, height and body condition score by an average of $0.1 \mathrm{~kg} / \mathrm{day}, 0.1 \mathrm{~mm} / \mathrm{day}$ and 0.5 units, respectively, during the supplementation period (Tables 5-7). From this time to $\sim 29$ months of age at the end of first mating for most heifers, the difference in average liveweight of $21 \mathrm{~kg}(13-27 \mathrm{~kg})$ between supplemented and unsupplemented heifers reduced steadily by between 2 and $14 \mathrm{~kg}$ (average of $7 \mathrm{~kg}$ or $35 \%$ ) per year (Tables 5,6). Likewise, the 13-28 mm (average
$21 \mathrm{~mm}$ ) height advantage conferred by post-weaning dry season supplementation was subsequently steadily eroded by $3-5 \mathrm{~mm}$ (average $4 \mathrm{~mm}$ or $20 \%$ ) per 100 days (Tables 5, 6). In the second dry season after weaning, heifers that had been given low-level post-weaning dry season supplementation continued to have lower rates of height gain in all cohorts in comparison to nonsupplemented heifers; a non-significant trend continued into the following wet season where it was measured in two cohorts (Table 6). Condition score differences due to supplementation were eliminated during the wet season after supplementation as weaners.

In this study where heifers weighing $<150 \mathrm{~kg}$ were offered low-energy supplements, the average difference between weaner size groups was reduced from $\sim 40 \mathrm{~kg}$ to $25 \mathrm{~kg}$ in the post-weaning dry season (Table 5). Much of this difference was maintained through to first mating at 2 years of age. Heavier heifers as weaners gained less height in each six-month period through to 2 years of age (Table 6). Therefore, in contrast to liveweight, hip height difference between heifer groups allocated on liveweight at weaning gradually reduced between weaning and 2-year-old mating from $\sim 6$ to $3 \mathrm{~cm}$ (Table 5). Body condition score was higher in bigger weaners in the middle of the postweaning dry season (Table 7), but thereafter, weaner liveweight had no effect on scores.

One month after weaning of the 1990 heifer cohort, ovariectomy had reduced liveweight by $5 \mathrm{~kg}(P<0.05)$. This effect disappeared within a further month and there were no other recorded effects of ovariectomy in that cohort. In contrast, ovariectomised 1993 weaners were 5-10 kg lighter than entire heifers from mid-August after weaning to 2 years of age $(P<0.05)$. This was associated with a $17-\mathrm{mm}$ hip height difference in the August after weaning, with no significant subsequent compensation. Body condition score was unaffected by ovariectomy.

Heifers pregnant initially at one year of age were $12-38 \mathrm{~kg}$ lighter, $11-14 \mathrm{~mm}$ shorter and up to 0.5 body condition score units lower than non-pregnant heifers at 26 months of age (Table 8).

Androstenedione vaccination had no effect on any growth parameter in any cohort.

\section{Discussion}

This research demonstrated the highly variable liveweight gain of juvenile female beef cattle between seasons in the northern forest country type of northern Australia, a function of the variation in rainfall between years, and the concentration of at least $75 \%$ of rainfall on average within 4 summer months, typically December-March. Average growth of non-supplemented heifers in the year after weaning was $\sim 105 \mathrm{~kg}$. This is consistent with the report of McLennan et al. (1988) that long-term average annual yearling steer growth is $100 \mathrm{~kg}$ at the same site with similar variation in annual and seasonal growth. Because of low and variable growth in this environment, many heifers are unable to reach weights sufficient to achieve high pregnancy rates in low-rainfall years. As the coefficient of variation for weight at puberty is $14 \%$ (Johnston et al. 2009) and assuming $95 \%$ of pubertal animals conceive, then to have $90 \%$ of heifers pregnant during maiden mating, they need to reach a liveweight at which the ratio with mature liveweight is at least $10 \%$ units 
Table 6. Weaner size and dry season supplement effects on heifer average daily weights gains and monthly hip height gains up to 2 years of age (see Tables 2 and 3 for treatment abbreviations)

Means with different letters within cohort $\times$ parameter time/period differ significantly $(P<0.05)$

\begin{tabular}{|c|c|c|c|c|c|c|c|c|c|c|c|}
\hline \multirow{3}{*}{\multicolumn{2}{|c|}{$\begin{array}{l} \\
\text { Time/Season: } \\
\text { Average heifer } \\
\text { age (m): }\end{array}$}} & \multicolumn{6}{|c|}{ Growth rates $(\mathrm{kg} /$ day $)$} & \multicolumn{4}{|c|}{ Hip height gain ( $\mathrm{mm} / \mathrm{month})$} \\
\hline & & \multirow{2}{*}{$\begin{array}{c}\text { Early dry } \\
5-9\end{array}$} & \multirow{2}{*}{$\begin{array}{l}\text { Late dry } \\
9-12\end{array}$} & Wet & \multirow{2}{*}{$\begin{array}{c}\text { Early dry } \\
17-21\end{array}$} & \multirow{2}{*}{$\begin{array}{c}\text { Late dry } \\
21-24\end{array}$} & \multirow{2}{*}{$\begin{array}{c}\text { Wet } \\
24-29\end{array}$} & \multirow{2}{*}{$\begin{array}{l}\text { Dry } \\
5-12\end{array}$} & \multirow{2}{*}{$\begin{array}{c}\text { Wet } \\
12-17\end{array}$} & \multirow{2}{*}{$\begin{array}{c}\text { Dry } \\
17-24\end{array}$} & \multirow{2}{*}{$\begin{array}{c}\text { Wet } \\
24-29\end{array}$} \\
\hline & & & & $12-17$ & & & & & & & \\
\hline \multicolumn{12}{|c|}{ Post-weaning dry season supplement } \\
\hline \multirow[t]{3}{*}{1987} & SL & $-0.06 \mathrm{a}$ & $-0.07 \mathrm{a}$ & $0.65 \mathrm{a}$ & 0.07 & -0.06 & $0.59 \mathrm{a}$ & $10.0 \mathrm{a}$ & 15.4 & $7.5 \mathrm{a}$ & - \\
\hline & $\mathrm{SH}$ & $0.08 \mathrm{~b}$ & $0.13 b$ & $0.61 b$ & 0.08 & -0.12 & $0.59 \mathrm{a}$ & $15.7 \mathrm{~b}$ & 14.7 & $5.8 \mathrm{~b}$ & - \\
\hline & SD & - & - & - & - & -0.09 & $0.55 \mathrm{~b}$ & - & - & $8.0 \mathrm{a}$ & - \\
\hline \multirow[t]{2}{*}{1989} & SL & - & $0.19 \mathrm{a}$ & $0.48 \mathrm{a}$ & \multicolumn{2}{|c|}{-0.16} & 0.53 & - & - & - & - \\
\hline & SH & - & $0.14 \mathrm{~b}$ & $0.45 b$ & \multicolumn{2}{|c|}{-0.13} & 0.51 & - & - & - & - \\
\hline \multirow[t]{2}{*}{1990} & SL & $-0.04 \mathrm{a}$ & $0.13 \mathrm{a}$ & 0.26 & $0.01 \mathrm{a}$ & -0.24 & 0.91 & - & 9.3 & $7.3 \mathrm{a}$ & - \\
\hline & SH & $0.10 \mathrm{~b}$ & $0.24 b$ & 0.24 & $-0.01 \mathrm{~b}$ & -0.26 & 0.90 & - & 8.9 & $6.1 \mathrm{~b}$ & - \\
\hline \multirow[t]{2}{*}{1991} & SL & $-0.02 \mathrm{a}$ & 0.01 & 0.67 & 0.18 & -0.02 & 0.60 & $8.4 \mathrm{a}$ & 16.3 & $8.9 \mathrm{a}$ & - \\
\hline & $\mathrm{SH}$ & $0.07 \mathrm{~b}$ & 0.00 & 0.68 & 0.16 & -0.03 & 0.60 & $10.1 \mathrm{~b}$ & 15.4 & $7.5 \mathrm{~b}$ & - \\
\hline \multirow[t]{2}{*}{1992} & SL & $0.09 \mathrm{a}$ & $0.00 \mathrm{a}$ & $0.45 \mathrm{a}$ & $-0.08 \mathrm{a}$ & $0.07 \mathrm{a}$ & 0.78 & $14.3 \mathrm{a}$ & $8.8 \mathrm{a}$ & $8.1 \mathrm{a}$ & 7.6 \\
\hline & $\mathrm{SH}$ & $0.19 b$ & $0.07 \mathrm{~b}$ & $0.49 \mathrm{~b}$ & $-0.18 b$ & $0.01 \mathrm{~b}$ & 0.75 & $17.9 \mathrm{~b}$ & $8.4 \mathrm{~b}$ & $7.0 \mathrm{~b}$ & 6.1 \\
\hline \multirow[t]{2}{*}{1993} & SL & $-0.03 a$ & -0.02 & 0.66 & 0.25 & 0.04 & 0.53 & $11.0 \mathrm{a}$ & 14.5 & $6.8 \mathrm{a}$ & 4.8 \\
\hline & $\mathrm{SH}$ & $0.06 \mathrm{~b}$ & 0.06 & 0.63 & 0.26 & 0.01 & 0.49 & $14.0 \mathrm{~b}$ & 12.6 & $5.9 \mathrm{~b}$ & 2.8 \\
\hline \multicolumn{12}{|c|}{ Weaner size group } \\
\hline \multirow[t]{2}{*}{1987} & WS & 0.01 & 0.03 & $0.62 \mathrm{a}$ & 0.09 & -0.07 & 0.59 & 12.5 & 15.7 & 7.9 & - \\
\hline & WA & 0.01 & 0.02 & $0.65 b$ & 0.06 & -0.10 & 0.58 & 13.1 & 14.4 & 6.1 & - \\
\hline \multirow[t]{7}{*}{$1989^{\mathrm{A}}$} & WV1 & - & $0.31 \mathrm{a}$ & $0.49 \mathrm{a}$ & & & 0.52 & - & - & - & - \\
\hline & WV2 & - & $0.25 \mathrm{ab}$ & $0.47 \mathrm{ab}$ & & & 0.53 & - & - & - & - \\
\hline & WV3 & - & $0.23 \mathrm{abc}$ & $0.47 \mathrm{abc}$ & & & 0.51 & - & - & - & - \\
\hline & WS1 & - & $0.21 \mathrm{~b}$ & $0.47 \mathrm{ab}$ & & & 0.54 & - & - & - & - \\
\hline & WS2 & - & $0.09 \mathrm{~d}$ & $0.44 \mathrm{bc}$ & & & 0.54 & - & - & - & - \\
\hline & WA1 & - & $0.13 \mathrm{~cd}$ & $0.49 \mathrm{a}$ & & & 0.51 & - & - & - & - \\
\hline & WA2 & - & $-0.05 \mathrm{e}$ & $0.43 \mathrm{c}$ & & & 0.48 & - & - & - & - \\
\hline 1990 & WS & 0.04 & 0.19 & 0.26 & 0.01 & $-0.21 \mathrm{a}$ & 0.89 & - & $10.1 \mathrm{a}$ & $7.1 \mathrm{a}$ & - \\
\hline & WA & 0.01 & 0.18 & 0.23 & 0.01 & $-0.28 b$ & 0.91 & - & $8.2 b$ & $6.2 \mathrm{~b}$ & - \\
\hline 1991 & WS & $0.08 \mathrm{a}$ & $0.07 \mathrm{a}$ & $0.65 \mathrm{a}$ & 0.16 & 0.01 & 0.60 & $11.7 \mathrm{a}$ & $17.3 \mathrm{a}$ & $8.5 \mathrm{a}$ & - \\
\hline & W1 & $0.02 b$ & $-0.03 b$ & $0.68 \mathrm{ab}$ & 0.16 & -0.02 & 0.60 & $8.4 \mathrm{~b}$ & $15.6 \mathrm{~b}$ & $8.7 \mathrm{a}$ & - \\
\hline & W2 & $-0.02 \mathrm{c}$ & $-0.02 b$ & $0.69 \mathrm{~b}$ & 0.19 & -0.06 & 0.60 & $7.7 \mathrm{~b}$ & $14.6 \mathrm{~b}$ & $7.4 \mathrm{~b}$ & - \\
\hline 1992 & WS & $0.18 \mathrm{a}$ & $0.07 \mathrm{a}$ & $0.44 \mathrm{a}$ & -0.10 & $0.07 \mathrm{a}$ & 0.76 & $17.9 \mathrm{a}$ & $9.4 \mathrm{a}$ & $8.7 \mathrm{a}$ & 6.6 \\
\hline & W1 & $0.12 \mathrm{~b}$ & $0.15 b$ & $0.46 \mathrm{a}$ & -0.15 & $0.03 b$ & 0.74 & $15.8 \mathrm{~b}$ & $9.0 \mathrm{a}$ & $7.0 \mathrm{~b}$ & 7.1 \\
\hline & W2 & $0.12 b$ & $-0.12 \mathrm{c}$ & $0.50 \mathrm{~b}$ & -0.15 & $0.02 b$ & 0.81 & $14.5 \mathrm{c}$ & $7.4 b$ & $6.9 \mathrm{~b}$ & 6.7 \\
\hline 1993 & WS & $0.07 \mathrm{a}$ & $0.10 \mathrm{a}$ & 0.62 & 0.24 & 0.05 & 0.50 & $14.3 \mathrm{a}$ & $16.5 \mathrm{a}$ & $7.6 \mathrm{a}$ & 3.8 \\
\hline & WA & $0.00 \mathrm{~b}$ & $0.04 \mathrm{a}$ & 0.64 & 0.26 & 0.02 & 0.51 & $12.5 \mathrm{~b}$ & $13.6 \mathrm{~b}$ & $6.5 \mathrm{~b}$ & 1.6 \\
\hline & WB & $-0.03 b$ & $-0.09 \mathrm{~b}$ & 0.68 & 0.26 & 0.01 & 0.51 & $10.6 \mathrm{c}$ & $10.6 \mathrm{c}$ & $5.1 \mathrm{c}$ & 6.0 \\
\hline
\end{tabular}

${ }^{\mathrm{A}}$ Heifers weaned at different times within the liveweight category at weaning were differentiated by an extra digit in their group description.

higher than that at puberty; for example, if puberty is at $63 \%$ of mature weight, heifers need to reach $\sim 73 \%$ of mature liveweight during mating, which is $325 \mathrm{~kg}$ for cows with a $445-\mathrm{kg}$ mature liveweight. Within cohort, up to $67 \%$ (average of $25 \%$ ) of heifers weaned at $100-149 \mathrm{~kg}$ and up to $25 \%$ (average of $9 \%$ ) of those weaned at $150+\mathrm{kg}$ within year group did not reach this target weight by 29 months of age, coinciding with the end of mating as a 2 year old.

Low-level supplementation in the post-weaning dry season that increased daily liveweight gain by an average of $0.1 \mathrm{~kg} /$ day preserved an average of approximately one-half of a body condition score over a 7-month period. This may be a critical reserve in years with extended dry seasons, thus reducing the risk of mortality. Supplementation did not significantly increase the percentage of any size weaners reaching the above-mentioned target liveweight of $325 \mathrm{~kg}$ at 29 months of age. The liveweight advantage due to low-level supplementation averaged $21 \mathrm{~kg}$ at the end of the post-weaning dry season; compensatory growth in unsupplemented heifers resulted in this difference averaging $14 \mathrm{~kg}$ and reducing at the end of the second dry season post-weaning at 24 months of age. In small weaner heifers (100-149 kg), the $15-\mathrm{kg}$ extra weight preserved through fortified molasses supplementation they received would also contribute to reducing the risk of mortality.

A third of the liveweight advantage due to low-level supplementation in the post-weaning dry season was lost in the following year, a well-recognised phenomenon known as compensatory gain (Winks et al. 1979). Ryan et al. (1990a, $1990 \mathrm{~b}$ ) explained this where growth of animals that have been on a low plane of nutrition and then restored to a high-quality diet, have reduced maintenance requirements initially, followed by higher feed intakes in comparison to animals continually fed 
Table 7. Weaner size and dry season supplement effects on heifer average body condition scores and seasonal changes in the post-weaning year (see Tables 2 and 3 for treatment abbreviations)

Means with different letters within cohort $\times$ parameter time/period differ significantly $(P<0.05)$

\begin{tabular}{|c|c|c|c|c|c|c|c|}
\hline \multirow{3}{*}{\multicolumn{2}{|c|}{$\begin{array}{l}\text { Time/Season: } \\
\text { Average heifer age: }\end{array}$}} & \multicolumn{3}{|c|}{ Condition } & \multicolumn{3}{|c|}{ Condition change } \\
\hline & & \multirow{2}{*}{$\begin{array}{c}\text { Weaning } \\
9\end{array}$} & \multirow{2}{*}{$\begin{array}{c}\text { Wet start } \\
12\end{array}$} & \multirow{2}{*}{$\begin{array}{c}\text { Mate } 1 \text { year } \\
14\end{array}$} & \multirow{2}{*}{$\begin{array}{c}\text { Early dry } \\
5-9\end{array}$} & \multirow{2}{*}{$\begin{array}{l}\text { Late dry } \\
9-12\end{array}$} & \multirow{2}{*}{$\begin{array}{l}\text { Wet } \\
12-17\end{array}$} \\
\hline & & & & & & & \\
\hline \multicolumn{8}{|c|}{ Post-weaning dry season supplement } \\
\hline \multirow[t]{2}{*}{1990} & SL & $2.5 \mathrm{a}$ & $2.1 \mathrm{a}$ & $2.2 \mathrm{a}$ & $-0.9 \mathrm{a}$ & $-0.5 \mathrm{a}$ & $0.8 \mathrm{a}$ \\
\hline & $\mathrm{SH}$ & $2.9 \mathrm{~b}$ & $2.6 \mathrm{~b}$ & $2.3 b$ & $-0.5 b$ & $-0.2 \mathrm{~b}$ & $0.4 \mathrm{~b}$ \\
\hline \multirow[t]{2}{*}{1991} & SL & 2.4 & $1.8 \mathrm{a}$ & 3.5 & -0.7 & -0.6 & $2.1 \mathrm{a}$ \\
\hline & $\mathrm{SH}$ & 2.8 & $2.5 b$ & 3.5 & -0.3 & -0.4 & $1.5 \mathrm{~b}$ \\
\hline \multirow[t]{2}{*}{1992} & SL & $2.9 \mathrm{a}$ & $2.3 \mathrm{a}$ & 3.5 & $-0.6 \mathrm{a}$ & $-0.7 \mathrm{a}$ & $1.2 \mathrm{a}$ \\
\hline & $\mathrm{SH}$ & $3.1 b$ & $2.7 \mathrm{~b}$ & 3.6 & $-0.4 b$ & $-0.5 b$ & $0.9 \mathrm{~b}$ \\
\hline \multirow[t]{2}{*}{1993} & SL & $2.8 \mathrm{a}$ & $2.1 \mathrm{a}$ & 2.6 & $0.2 \mathrm{a}$ & $-0.7 \mathrm{a}$ & $1.4 \mathrm{a}$ \\
\hline & $\mathrm{SH}$ & $3.1 \mathrm{~b}$ & $2.4 \mathrm{~b}$ & 2.7 & $0.3 \mathrm{~b}$ & $-0.8 \mathrm{~b}$ & $1.2 \mathrm{~b}$ \\
\hline \multicolumn{8}{|c|}{ Weaner size group } \\
\hline \multirow[t]{2}{*}{1990} & WS & $2.5 \mathrm{a}$ & $2.2 \mathrm{a}$ & 2.2 & -0.8 & -0.3 & $0.7 \mathrm{a}$ \\
\hline & WA & $2.9 \mathrm{~b}$ & $2.5 b$ & 2.3 & -0.6 & -0.4 & $0.5 b$ \\
\hline \multirow[t]{3}{*}{1991} & WS & 2.5 & 2.2 & 3.5 & -0.5 & -0.3 & 1.7 \\
\hline & W1 & 2.6 & 2.0 & 3.4 & -0.5 & -0.6 & 1.9 \\
\hline & W2 & 2.7 & 2.1 & 3.5 & -0.6 & -0.6 & 1.8 \\
\hline \multirow[t]{3}{*}{1992} & WS & $2.9 \mathrm{a}$ & $2.5 \mathrm{~b}$ & $3.5 \mathrm{a}$ & -0.4 & $-0.4 \mathrm{a}$ & $1.0 \mathrm{a}$ \\
\hline & W1 & $2.9 \mathrm{a}$ & $2.6 \mathrm{a}$ & $3.6 \mathrm{~b}$ & -0.6 & $-0.3 \mathrm{a}$ & $0.9 \mathrm{a}$ \\
\hline & W2 & $3.3 b$ & $2.3 b$ & $3.5 \mathrm{ab}$ & -0.4 & $-0.9 \mathrm{~b}$ & $1.2 \mathrm{~b}$ \\
\hline \multirow[t]{3}{*}{1993} & WS & $2.8 \mathrm{a}$ & 2.2 & 2.6 & $0.3 \mathrm{a}$ & $-0.5 \mathrm{a}$ & 1.2 \\
\hline & WA & $3.1 b$ & 2.3 & 2.7 & $0.3 \mathrm{a}$ & $-0.8 \mathrm{~b}$ & 1.3 \\
\hline & WB & $3.2 b$ & 2.3 & 2.6 & $0.1 \mathrm{~b}$ & $-0.9 \mathrm{~b}$ & 1.3 \\
\hline
\end{tabular}

Table 8. Maiden mating age effects on heifer growth between 17 months and the start of maiden mating at 2 years of age Means with different letters within cohort $\times$ parameter time/period differ significantly $(P<0.05)$

\begin{tabular}{|c|c|c|c|c|c|c|c|}
\hline Time & Age (months) & $\begin{array}{c}\text { Mate } 1 \text { year - } \\
\text { Pregnant }\end{array}$ & $\begin{array}{l}1991 \text { cohort } \\
\text { Mate } 1 \text { year - } \\
\text { Not Pregnant }\end{array}$ & Mate 2 year & $\begin{array}{c}\text { Mate } 1 \text { year - } \\
\text { Pregnant }\end{array}$ & $\begin{array}{l}1992 \text { cohort } \\
\text { Mate } 1 \text { year - } \\
\text { Not Pregnant }\end{array}$ & Mate 2 year \\
\hline \multicolumn{8}{|c|}{ Weight $(\mathrm{kg})$} \\
\hline April/May & 17 & 279 & 276 & 272 & $256 a$ & $256 \mathrm{a}$ & $270 \mathrm{~b}$ \\
\hline Aug./Sept. & 21 & $281 \mathrm{a}$ & $279 \mathrm{a}$ & $293 b$ & $248 \mathrm{a}$ & $250 \mathrm{a}$ & $261 b$ \\
\hline Wet start & 24 & $275 \mathrm{a}$ & $291 b$ & $281 \mathrm{a}$ & $240 \mathrm{a}$ & $243 a$ & $278 \mathrm{~b}$ \\
\hline Mate 2 year & 26 & $294 \mathrm{a}$ & $332 \mathrm{~b}$ & $331 \mathrm{~b}$ & $273 a$ & $285 b$ & $307 \mathrm{c}$ \\
\hline \multicolumn{8}{|c|}{ Growth rate (kg/day) } \\
\hline Early dry & $17-21$ & $0.03 \mathrm{a}$ & $0.05 \mathrm{a}$ & $0.29 b$ & -0.13 & 0.10 & -0.16 \\
\hline Late dry & $21-24$ & $-0.05 \mathrm{a}$ & $0.11 \mathrm{~b}$ & $-0.10 \mathrm{a}$ & $-0.08 \mathrm{a}$ & $-0.06 \mathrm{a}$ & $0.15 b$ \\
\hline Wet & $24-29$ & $0.25 \mathrm{a}$ & $0.64 b$ & $0.70 \mathrm{c}$ & $0.44 \mathrm{a}$ & $0.95 \mathrm{c}$ & $0.79 b$ \\
\hline \multicolumn{8}{|c|}{ Hip height $(\mathrm{mm})$} \\
\hline April/May & 17 & 1226 & 1226 & 1222 & $1198 \mathrm{a}$ & $1217 b$ & $1218 b$ \\
\hline Wet start & 24 & 1265 & 1268 & 1278 & $1238 \mathrm{a}$ & $1260 \mathrm{~b}$ & $1263 b$ \\
\hline \multicolumn{8}{|c|}{ Hip height change (mm/day) } \\
\hline Dry & $17-24$ & $0.214 \mathrm{a}$ & $0.228 \mathrm{a}$ & $0.31 \mathrm{~b}$ & 0.23 & 0.24 & 0.26 \\
\hline Wet & $24-29$ & & & & $0.08 \mathrm{a}$ & $0.28 \mathrm{~b}$ & $0.25 b$ \\
\hline \multicolumn{8}{|c|}{ Body condition score (1-5) } \\
\hline April/May & 17 & & & & $3.4 \mathrm{a}$ & $3.2 \mathrm{~b}$ & $3.6 \mathrm{c}$ \\
\hline Aug./Sept. & 21 & $3.3 \mathrm{a}$ & $3.2 \mathrm{a}$ & $3.7 \mathrm{~b}$ & $3.5 \mathrm{a}$ & $3.3 b$ & $3.6 \mathrm{a}$ \\
\hline Wet start & 24 & 2.8 & 3.1 & 2.9 & $2.4 \mathrm{a}$ & $2.3 \mathrm{a}$ & $2.9 \mathrm{c}$ \\
\hline Mate 2 year & 26 & $2.8 \mathrm{a}$ & $3.8 \mathrm{~b}$ & $3.8 \mathrm{~b}$ & $2.8 \mathrm{a}$ & $3.4 \mathrm{~b}$ & $3.6 \mathrm{c}$ \\
\hline \multicolumn{8}{|c|}{ Body condition score change (1-5) } \\
\hline Early dry & $17-21$ & $-0.6 \mathrm{a}$ & $-0.5 \mathrm{a}$ & $-0.2 \mathrm{~b}$ & 0.0 & 0.0 & 0.0 \\
\hline Late dry & $21-24$ & $-0.4 \mathrm{a}$ & $0.0 \mathrm{~b}$ & $-0.7 \mathrm{c}$ & $-1.1 \mathrm{a}$ & $-1.0 \mathrm{a}$ & $-0.6 b$ \\
\hline Wet & $24-29$ & $0.0 \mathrm{a}$ & $0.3 b$ & $0.5 \mathrm{c}$ & $0.0 \mathrm{a}$ & $1.4 \mathrm{~b}$ & $0.9 \mathrm{c}$ \\
\hline
\end{tabular}


a high-quality diet. Ryan et al. (1990a, 1990b) demonstrated full compensation in liveweight over an 11-month period. Our studies have shown compensation can occur over more than 1 year. In a study with steers that were supplemented in consecutive dry seasons in comparison to non-supplemented steers, McLennan (2014) also reported compensation in liveweight occurring over more than 1 year.

Compensatory growth as indicated by negative correlations of liveweight and body condition score changes between consecutive wet and dry seasons also occurred; i.e. heifers able to gain more liveweight and body condition during wet seasons, lost it at greater rates during dry seasons. A possible reason for this could be differential adaptation to stressors between dry and wet seasons; i.e., growth advantage in one season due to better adaptation to prevailing stressors may be lost in a subsequent season when different stressors exist. Wet season stressors include buffalo fly (Haemotobia iritans exigua), cattle tick (Ripicephalus microplus), high temperatures and humidity, viruses transmitted by vectors more likely to be present during moist conditions, and irregular instances of extreme weather. In contrast, the major stressors in the dry season are sub-maintenance nutrition throughout, high ambient temperatures late in the dry season, and ongoing low-level ectoparasitism. Another possible component of the seasonal effect is photoperiod as Rius et al. (2005) showed that long daylength alone can increase average daily gain and hip height gain in dairy calves over a 7 -month period by $10 \%$ and $15 \%$, when Control calves gained $\sim 1 \mathrm{~kg} /$ day and $1.20 \mathrm{~mm} /$ day, respectively. Our studies were unable to verify such an effect.

At 6 months of age, heifers at weaning were on average gaining height at $\sim 0.60 \mathrm{~mm} /$ day, with the rate of height gain decelerating by $\sim 0.00075 \mathrm{~mm} /$ day thereafter; this result is not to be extrapolated beyond 2.5 years of age. This deceleration explains the inverse relationship between 6-monthly height gains and liveweight at weaning as taller heifers would on average be older at weaning. Deceleration of height gain is expected when annual weight gain remains relatively constant as these are single- and multi-dimensional measures, respectively.

A feature of this research was that skeletal growth, a function of bone elongation, continues while losing soft body tissue, also reported by Fordyce et al. (2013). This occurred during both the first and second dry seasons after weaning when reductions of up to two body condition score units were seen. Though bone growth continued during nutritional deprivation, it was retarded. Low-level dry season supplementation had smaller effects on height gain than occurred due to year effects within season. Heifers pregnant as yearlings had retarded bone growth through to 2.5 years of age in comparison to those non-pregnant as yearlings as a result of the nutritional demands of gestation and lactation. The overall impact of generally low nutrition in the study reported here was reflected in average height of the heifers at 24 months of age at the end of a dry season being $52 \mathrm{~mm}$ lower than the tropical composites used in the study of Fordyce et al. (2013), which had a mature height only $25 \mathrm{~mm}$ higher and which had received a higher plane of nutrition from weaning.

Other reports have also found significant differences in skeletal development of young cattle experiencing different nutrition (Matthews et al. 2008; McLennan 2014). Davis Rincker et al. (2008) showed that increasing growth rate from $\sim 0.6 \mathrm{~kg} /$ day to $\sim 1.1 \mathrm{~kg} /$ day in dairy heifers aged 2 months of age increased height gain by $40 \mathrm{~mm}$ over 12 weeks when low-growth heifers gained $100 \mathrm{~mm}$ in height. Gabler and Heinrichs (2003) presented evidence from studies with 4-9-month-old dairy calves that increasing dietary protein level, but keeping diet energy levels constant, increased skeletal growth without increasing overall bodyweight gain, thus indicating the importance of dietary protein in skeletal growth management. Silva et al. (2016) showed that restricting dietary energy reduced hip height gain in young steers from $1.05 \mathrm{~mm}$ to just $0.42 \mathrm{~mm}$ /day during a 103-day feeding period with protein restriction reducing gain even further to $0.30 \mathrm{~mm} /$ day.

For the first time for beef cattle in northern Australia, our research showed that compensatory skeletal development occurs following dry seasons in juvenile female cattle, and this compensation can continue for at least 12 months. Silva et al. (2014) had reported a non-significant trend for compensatory growth of the skeleton in a penned steer study over a short period of just 94 days. The review of Boersma and Wit (1997) from several species concluded that under-nutrition can slow overall body growth, including epiphyseal plate growth, but once growth restrictions are removed, the rate of skeletal growth can increase to return the animal to a growth plane expected without growth restriction. Bone elongation is a result of cell proliferation, hypertrophy and vascular invasion in epiphyseal growth plates. Fordyce et al. (2013) indicated that epiphyseal growth plate closure occurs at an average of 4.5 years of age in north Australian female beef cattle. Limited available studies from several mammalian species, including humans, suggest that ultimate bone growth may be determined by defined limited lifetime cell proliferation within growth plates (Lui and Baron 2011). Though elevated oestrogen levels around puberty are associated with higher rates of epiphyseal plate growth (Boersma and Wit 1997; Kuczmarski et al. 2002; cited by Lui and Baron 2011), slowing of epiphyseal plate growth is promoted by, though not dependent on, oestrogen (Lui and Baron 2011). Despite these known effects of oestrogen, vaccination against the closely related androstenedione had no impact on height gain in our studies.

The review of Boersma and Wit (1997) described accelerated or compensatory elongated bone growth following retardation as canalisation. Cell programming at the growth plate level may be responsible for recovery of bone elongation to predetermined age-related stages (Lui and Baron 2011). Gafni et al. (2001) previously described the possible mechanism for this using a study with rabbits where growth retardation appeared to cause growth plate senescence. Once nutritional restrictions are removed, the growth plate is more 'physiologically immature' and therefore there are higher rates of bone elongation than in animals that have not experienced the same level of growth restriction. Evidence of canalisation in the heifers in this study is provided by them being $100 \mathrm{~mm}$ shorter at 12 months of age than tropical composites reared under better nutritional conditions that are only slightly taller at maturity (Fordyce et al. 2013) with this difference being halved by 24 months age, and was expected to be $25 \mathrm{~mm}$ by 4.5 years of age. Whatever mechanisms are operating, female cattle may only be able to achieve growth plate compensatory growth till $\sim 4.5$ years of age as anecdotal evidence is that in very low growth regions, cows fail to reach mature size if they do not 
attain it at 4.5 years of age as a result of extended growth retardation; this is called stunting. This hypothesis remains to be proven.

Several studies have shown substantial reductions in daily liveweight gain following ovariectomy of heifers; these include retardation by $0.13 \mathrm{~kg}$ /day in the 2 months following surgery (Fordyce et al. 2001), $0.4 \mathrm{~kg} /$ day between 11 days before and 21 days after surgery (Petherick et al. 2011), and $0.11 \mathrm{~kg} /$ day in the 42 days following surgery (McCosker et al. 2010). Fordyce et al. (2001) also showed no subsequent compensatory growth. These outcomes are consistent with our findings of short-term growth retardation without subsequent compensatory growth. The reason for no growth compensation is unknown. Ovariectomy being an acute rather than chronic intervention may be associated with the reason. Also, the removal of ovaries that are a significant source of oestrogen, which promotes growth of epiphyseal plates as discussed above, may be a contributing cause.

The main conclusion from this research is that heifer growth in the dry tropical northern forest region of northern Australia is highly variable between seasons and years, thus limiting significant proportions of some cohorts from reaching target weights for mating at 2 years of age. Gains in hip height continually decelerated from weaning and were less affected by under-nutrition than either liveweight or body condition. Periods of poor nutrition, including that secondary to nutritional demand for reproduction were associated with suppressed daily gains in liveweight, hip height and reduction in body condition score. Subsequent to periods of poor nutrition, partial to full compensation occurred for all measures, with rate of recovery being highest for body condition. Though low-level supplementation in the post weaning dry season preserved half a condition score, liveweight advantages conferred by 2 years of age were very small. Ovariectomy had negative effects on growth, but vaccination had no measurable impacts.

\section{Conflict of interest}

The authors declare no conflicts of interest.

\section{Acknowledgements}

This research was partially funded by Meat and Livestock Australia through project DAQ.062. We acknowledge the contribution of many Swan's Lagoon station staff plus the professional contributions from Neil Cooper, the late Ian Kendall, Bernadette Lyttle, Tom Mullins, Andrew Beattie, Kieren Hobbs, Dr Michael D'Occhio, Linus Hellqvist, Alison McIvor, the late Professor Keith Entwistle and Professor Lee Fitzpatrick.

\section{References}

Barwick SA, Johnston DJ, Burrow HM, Holroyd RG, Fordyce G, Wolcott ML, Sim WD, Sullivan MT (2009) Genetics of heifers performance in 'wet' and dry' seasons and their relationships with steer performance in two tropical beef genotypes. Animal Production Science 49, 367-382. doi:10.1071/EA08273

Boersma B, Wit JM (1997) Catch-up growth. Endocrine Reviews 18, 646-661. doi:10.1210/edrv.18.5.0313

Bortolussi G, McIvor JG, Hodgkinson JJ, Coffey SG, Holmes CR (2005) The northern Australian beef industry, a snapshot. 3. Annual liveweight gains from pasture based systems. Australian Journal of Experimental Agriculture 45, 1093-1108. doi:10.1071/EA03098
D’Occhio MJ, Gifford DR, Hoskinson RM, Weatherly T, Setchell BP (1988) Gonadotrophin secretion and ovarian responses in prepubertal; heifers actively immunised against androstenedione and oestradiol-17 $\beta$. Journal of Reproduction and Fertility 83, 159-168. doi:10.1530/jrf.0.0830159

Davis Rincker LE, Weber Nielsen MS, Chapin LT, Liesman JS, VandeHaar MJ (2008) Effects of feeding prepubertal heifers a high-energy diet for three, six, or twelve weeks on feed intake, body growth, and fat deposition. Journal of Dairy Science 91, 1913-1925. doi:10.3168/jds.2006-210

Fordyce G, Holroyd RG (2003) Management of extensive northern beef breeding herds. In 'Proceedings of the Australian Association of Cattle Veterinarians 2003 - Cairns Conference'. pp. 16-30. (Australian Cattle Veterinarians: Brisbane)

Fordyce G, James TA, Holroyd RG, Beaman NJ, Mayer RJ, O’Rourke PK (1993a) The performance of Brahman-Shorthorn and Sahiwal-Shorthorn beef cattle in the dry tropics of northern Queensland. 3. Birth weights and growth to weaning. Australian Journal of Experimental Agriculture 33, 119-127. doi:10.1071/EA9930119

Fordyce G, Loxton ID, Holroyd RG, Tyler R, Howitt CJ, Mayer RJ (1993b) The performance of Brahman-Shorthorn and Sahiwal-Shorthorn beef cattle in the dry tropics of northern Queensland. 4. Post-weaning growth and carcass traits. Australian Journal of Experimental Agriculture 33, 531-539. doi:10.1071/EA9930531

Fordyce G, Jubb TF, Fitzpatrick LA, Whyte TR, Cooper NJ, Bolam MJ, Haddon DJ, Hill F, D'Occhio MJ (2001) Contraceptive efficacy of an intra-uterine device in Brahman cattle. Animal Reproduction Science 65, 193-204. doi:10.1016/S0378-4320(01)00081-1

Fordyce G, Anderson A, McCosker KD, Williams PJ, Holroyd RG, Corbet NJ, Sullivan MS (2013) Liveweight prediction from hip height, condition score, fetal age and breed in tropical female cattle. Animal Production Science 53, 275-282. doi:10.1071/AN12253

Gabler MT, Heinrichs AJ (2003) Dietary protein to metabolizable energy ratios on feed efficiency and structural growth of prepubertal Holstein heifers. Journal of Dairy Science 86, 268-274. doi:10.3168/jds.S00220302(03)73605-4

Gaden B (2005) Final Report, Project LIVE.120, Meat and Livestock Australia, North Sydney.

Gafni RI, Weise M, Robrecht DT, Meyers JL, Barnes KM, De-Levi S, Baron J (2001) Catch-up growth is associated with delayed senescence of the growth plate in rabbits. Pediatric Research 50, 618-623. doi:10.1203/ 00006450-200111000-00014

Holroyd RG (1978) Methods of investigating beef cattle fertility. In 'Beef cattle production in the Tropics'. (Eds RM Murray, KW Entwistle) pp. 233-246. (James Cook University Press: Townsville)

Holroyd RG, James TA, Anderson VJ, Fordyce G, Tyler R, O’Rourke PK (1990) The performance of Brahman-Shorthorn and Sahiwal-Shorthorn beef cattle in the dry tropics of northern Queensland. 2. Reproductive rates and liveweight of F2 et seq. females. Australian Journal of Experimental Agriculture 30, 727-733. doi:10.1071/EA9900727

Johnston DJ, Barwick SA, Corbet NJ, Fordyce G, Holroyd RG, Williams PJ, Burrow HM (2009) Genetics of heifer puberty in two tropical beef genotypes in northern Australia and associations with heifer- and steerproduction traits. Animal Production Science 49, 399-412. doi:10.1071/ EA08276

Kinder JE, Bergfield EGM, Wehrman ME, Peters KE, Kojima FN (1995) Endocrine basis for puberty in heifers and ewes. Journal of Reproduction and Fertility. Supplement 49, 393-407.

Kuczmarski RJ, Ogden CL, Guo SS, Grummer-Strawn LM, Flegal KM, Mei Z, Wei R, Curtin LR, Roche AF, Johnson CL (2002) 2000CDC growth charts for the United States: methods and development. Vital Health Statistics 11, 1-190.

Lui JC, Baron J (2011) Mechanisms limiting body growth in mammals. Endocrine Reviews 32, 422-440. doi:10.1210/er.2011-0001 
Matthews RA, Fordyce G, Poppi DP (2008) Nutritional management of skeletal bone growth in cattle in the dry tropics. Proceedings of the Australian Society of Animal Production 27, 57.

McCosker TH, Winks L (1994) 'Phosphorus nutrition of beef cattle in northern Australia.' (Department of Primary Industries: Qld)

McCosker K, Letchford P, Petherick JC, Mayer D, McGowan MR (2010) Morbidity, mortality and body weight gain of surgically spayed, yearling Brahman heifers. Australian Veterinary Journal 88, 497-503. doi:10.1111/ j.1751-0813.2010.00646.x

McGowan MR, McCosker K, Fordyce G, Smith D, O'Rourke PK, Perkins N, Barnes T, Marquet L, Morton J, Newsome T, Menzies D, Burns BM, Jephcott S (2014) North Australian beef fertility project: Cash Cow. Final Report, Project B.NBP.0382, Meat and Livestock Australia, Sydney. Available at https://www.mla.com.au/research-and-development/searchrd-reports/final-report-details/Productivity-On-Farm/Northern-Australianbeef-fertility-project-CashCow/370 [Verified 23 November 2017]

McLennan SR (2014) Optimising growth paths of beef cattle in northern Australia for increased profitability. Final Report, Project B.NBP.0391, Meat and Livestock Australia, Sydney. Available at https://www.mla. com.au/research-and-development/search-rd-reports/final-report-details/ Productivity-On-Farm/Optimising-growth-paths-of-beef-cattle-in-northernAustralia-for-increased-profitability/372 [Verified 13 November 2017]

McLennan SR, Hendricksen RE, Beale IF, Winks L, Miller CP, Quirk MF (1988) Nutritive value of pastures in Queensland. In 'Native pastures in Queensland: the resources and their management'. Information Series QI87023. (Eds WH Burrows, JC Scanlan, MT Rutherford) pp. 125-159. (Department of Primary Industries, Queensland: Brisbane)

Payne RW, Harding SA, Murray DA, Soutar DM, Baird DB (2008) 'Genstat Release 13.' (VSN International Pty Ltd: Hemel Hempstead, Hertfordshire, UK)

Petherick JC, McCosker K, Mayer D, Letchford P, McGowan MR (2011) Preliminary investigation of some physiological responses of Bos indicus heifers to surgical spaying. Australian Veterinary Journal 89, 131-137. doi:10.1111/j.1751-0813.2011.00696.x

Rius AG, Connor EE, Capuco AV, Kendall PE, Achtung-Montgomery TL, Dahl GE (2005) Long-Day photoperiod that enhances puberty does not limit body growth in Holstein heifers. Journal of Dairy Science 88, 4356-4365. doi:10.3168/jds.S0022-0302(05)73122-2

Ryan WJ, Williams IH, Moir RJ (1990a) Compensatory growth in sheep and cattle. I. Growth pattern and feed intake. Australian Journal of Agricultural Research 44, 1609-1621. doi:10.1071/AR9931609

Ryan WJ, Williams IH, Moir RJ (1990b) Compensatory growth in sheep and cattle. II. Changes in body composition and tissue weights. Australian Journal of Agricultural Research 44, 1623-1633. doi:10.1071/ AR9931623

Silva TACC, Quigley S, Kidd L, McLennan S, Poppi D (2014) Skeletal growth, liveweight gain and feed intake of Bos indicus and Bos taurus cattle undergoing compensatory liveweight gain. Animal Production in Australia 30, 289

Silva TACC, Kidd LJ, Quigley SP, McLennan SR, Anderson ST, Poppi DP (2016) High protein content stimulates bone elongation on energyrestricted cattle. Animal Production in Australia 31, 1264.

Smith DR, Fordyce G, Shaw KA, Smith PC, Laing AR (2001) Northern stocking rate demonstration. Project report NHT.962011, National Heritage Trust, Canberra.

Winks L, Laing AR, O'Rourke PK, Wright GS (1979) Factors affecting response to urea-molasses supplements by yearling cattle in tropical Queensland. Australian Journal of Experimental Agriculture and Animal Husbandry 19, 522-529. doi:10.1071/EA9790522

Wolcott ML, Johnston DJ, Barwick SA, Corbet NJ, Williams PJ (2014) The genetics of cow growth and body composition at first calving in two tropical beef genotypes. Animal Production Science 54, 37-49. doi:10.1071/AN12427 